\title{
Antiplasmodial activity of stem bark and leaves of Alstonia boonei (De Wild)
}

\begin{abstract}
The recent report on patterns of malaria endemicity in Nigeria continues to show high levels of burden across the country with majority of the population at risk. Therefore, the development of safe and effective anti-malarial drug from locally grown medicinal plants may serve as an alternative for novel drugs for malaria control. Especially, in rural areas deprived of modern antimalarial with record of high mortality. This study was carried out to evaluate in vivo antiplasmodial effect of methanolic and aqueous extracts of Alstonia boonei leaves and stem bark. The qualitative and quantitative phytochemical analysis of the extracts were carried out using standard methods. The in vivo anti-plasmodial effect against infection was studied using 4-day suppressive test in chloroquine sensitive Plasmodium berghei NK65-infected mice. Results of the phytochemical tests showed that alkaloids and terpenoids were absent in aqueous extracts. Quantitative screening of the methanolic extract of leaves revealed the presence of tannins (14.75\%), alkaloids $(8.79 \%)$ and terpenoids $(7.19 \%)$. The suppressive test revealed that methanolic and aqueous leave extracts exerted significant $(\mathrm{P}<.05)$ dose-dependent reduction against the parasite. The administered dosages $500 \mathrm{mg} / \mathrm{kg}$ body weight per day of Alstonia boonei methanolic and aqueous extracts of leaves caused chemo suppression of $97.80 \%$ and $71.42 \%$ respectively on day four, similar dosages of methanolic and aqueous stem bark extracts caused chemo suppression of $89.59 \%$ and $72.89 \%$ respectively on day four. In conclusion, Alstonia boonei contained active antiplasmodial compounds and therefore might be a potential antimalarial drug.
\end{abstract}

Keywords: antiplasmodial, suppressive, chemo suppression, extracts
Volume 7 Issue 5 - 2019

\author{
Funmilola Omoya, Taiwo Folayele Oyebola \\ Department of Microbiology, School of Sciences, Federal \\ University of Technology, Nigeria
}

Correspondence: Funmilola Omoya, Department of Microbiology, School of Sciences, Federal University of Technology,Akure, Nigeria, Email fomoya@yahoo.com

Received: September 26, 2019 | Published: October 03, 2019

\section{Introduction}

Malaria is one of the world's leading epidemic widely spread in tropical and subtropical areas. ${ }^{1}$ The disease kills 1 million people worldwide annually, and an estimated 700,000 of them are children. ${ }^{2}$ Malaria is said to kill a child every 30 seconds, since with the onset of severe malaria, death may occur within $24 \mathrm{~h}$ or less. ${ }^{3}$ In Nigeria, malaria accounts for 30\%-50\% morbidity and $25 \%$ mortality in infants (Idowu et al., 2010). According to world malaria report 2017, Nigeria accounted for the highest proportion of global malaria cases $(27 \%){ }^{4}$ During the past 30 years, malaria parasites especially Plasmodium falciparum ( $P$. falciparum) have rapidly developed resistance to commonly used antimalarial drugs. ${ }^{5}$ Due to the fact that effective vaccine to control malaria has not been successfully developed, hence antimalarial drugs are mainly focused. This has prompted research towards the development and discovery of new, safe, and affordable antimalarial chemotherapies. During last decade, several demonstrations have been conducted to explore antimalarial activity of many plants, including curcumin,,${ }^{6,7}$ green tea ${ }^{8}$ and others. ${ }^{9}$

The greatest impact of the disease is on the poor people of the world and most of these populations are found in the rural settings especially in African communities where the people have poor nutritional status and also lack access to good health facilities. Thus, the rural dwellers depend more on herbs and other forms of traditional medicines for cure. ${ }^{5,10}$ The development of safe and effective anti- malarial preparations by simple procedures from locally grown medicinal plants may offer new and complimentary drugs for malaria control, especially in remote geographical locations and rural areas where modern antimalarial drugs are not readily available and malaria mortality is higher. In countries where malaria is endemic, including Nigeria; medicinal plants have served as sole source or alternative therapy for malaria for quite a long time. This practice has its origins in folklore and cultural practices. ${ }^{11}$ The feasibility of discovering new potent antimalarials from traditional medicinal plants is very promising. ${ }^{12}$

Alstonia boonei (De Wild), also called devil tree in tropical and sub-tropical Africa, Central America and Australia, is a large deciduous evergreen tree, also known as "Ahun" in Yoruba, "Egbuora" in Igbo, "Ukhu" in Edo and "Ukpukunu" in Urhobo. The plant is widely distributed in the lowlands and rain-forest areas of Nigeria. ${ }^{13}$ The usefulness of the medicinal plants may hold the key to another new and effective antimalarial drug in the future. Indigenous medicinal plants in Nigeria used in combating malaria are yet to be projected in conferences as the foreign plants in spite of our rich flora diversity. ${ }^{14}$ Therefore, this present study aimed at presenting the antiplasmodial activities of stem bark and leaves of Alstonia boonei the plant mostly used for malaria therapy in Ipole Iloro Ekiti, Ekiti West Local Government Area, Ekiti state, Nigeria 


\section{Materials and methods}

\section{Identification and authentication of the plant used}

The fresh leaves and stem bark of Alstonia boonei plant were collected in August, 2015 from a farmland at IpoleIloro, Ekiti West Local Government, Area, Ekiti State, SouthWestern Nigeria. The plant materials were identified and authenticated by a Plant Scientist (Dr. L. Fayehun), in the Department of Crop Soil and Pest Management, School of Agriculture and Agricultural Technology, The Federal University of Technology, Akure (Plate 1).

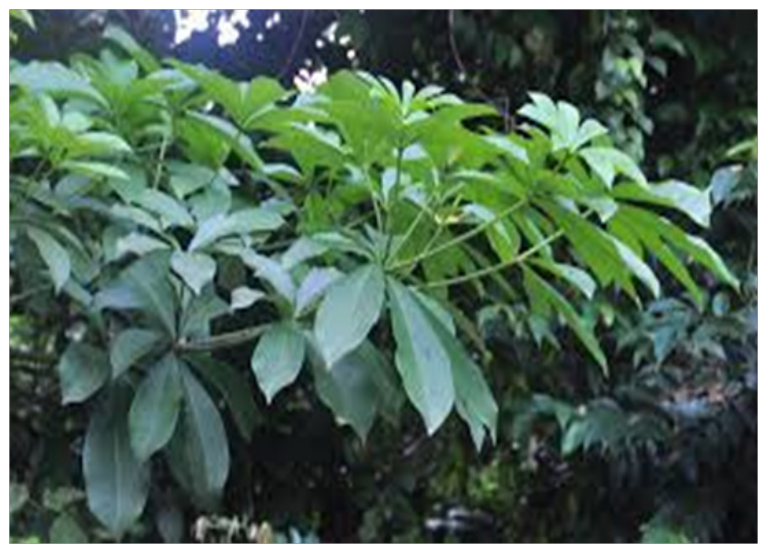

Plate I Photograph of Alstonia boonei plant from its natural habitat.

\section{Extraction of plant}

The fresh leaves and stem back were washed with sterile distilled water; air dried and grounded using a grinder mill. Extraction of plant material was performed by soxhlet apparatus (Sigma-Aldrich, USA) using methanol and water. About $50 \mathrm{~g}$ of the extract was put into a $500 \mathrm{ml}$ conical flask and soaked in $300 \mathrm{ml}$ of $70 \%$ Methanol for methanolic extract and $300 \mathrm{ml}$ of water for aqueous extract. This was then left to stand overnight and mixed thoroughly for 3 hours on a mechanical shaker (Celltron, Switzerland). The content was filtered using a non-absorbent cotton wool on a Buchner funnel-flask using a vacuum pump. The residue was subjected to several parts of rinsing and filtration with fresh solvents to attain some level of exhaustive maceration. The filtrate was concentrated by evaporating to dryness using a rotary evaporator (Sigma-Aldrich, USA). The dried extract was used for phytochemical analysis and anti-plasmodial assay in experimental albino mice.

\section{Phytochemical analysis for the plant extracts}

The methanolic and aqueous extracts of leave and stem back were subjected to qualitative and quantitative phytochemical screening according to the method of Trease and Evans ${ }^{15}$ to detect the presence or absence of plant secondary metabolites: saponins, tannins, alkaloids, flavonoids, steroids, anthraquinones, and cardiac glycosides according to the method of Trease and Evans. ${ }^{15}$ The extracts were kept in refrigerator for further use. Before use, powdered crude extract was freshly dissolved in tween 80 to obtain appropriate doses

\section{Acute toxicity test}

Acute toxicity test of Alstonia boonei extracts were carried out as previously described. ${ }^{16}$ Groups of mice (5 mice of each) were given $250,500,1,000,2,000,4,000$ and $6,000 \mathrm{mg} / \mathrm{kg}$ body weight of the extract orally by gavage. The mice were then observed for signs of toxicity which include but not limited to paw licking, salivation, stretching of entire body, weakness, sleeping, respiratory distress, coma and death in first 4 hours and subsequently daily for 7 days.

\section{Experimental mice}

Four weeks old male and female $(20-25 \mathrm{~g})$ swiss albino mice were collected from the Animal house at Afe Babalola University, Ado-Ekiti, Ekiti State and Obafemi Awolowo University, Ile-Ife, Osun State. The mice were conveniently housed under standard environmental condition at $22-25^{\circ} \mathrm{C}$ for acclimatization before the experiments. All mice were fed with commercial feed pellets and clean water throughout the study. All mice use in these experiments were approved and ratified by the Animal Ethic Committee, Department of Animal Production and Health, School of Agriculture and Agricultural Technology, Federal University of Technology, Akure.

\section{Parasites strain}

In vivo antimalarial testing in mice was done using chloroquine sensitive strain of Plasmodium berghei (donated by the Animal Unit, the Institute for Advanced Medical Research and training, College of Medicine, UCH, Ibadan). The parasites stock was maintained by continuous re-infection in the mice.

\section{Preparation of Inoculum}

Donor Plasmodium berghei infected mice were subjected to chloroform in a container were used and the blood was collected by heart puncture. Heparinized blood is taken from a donor mouse with approximately $30 \%$ parasitemia. The blood was diluted with 5 $\mathrm{ml}$ of phosphate buffer solution (PBS) $\mathrm{pH} 7.2$ so that each $0.2 \mathrm{ml}$ contained approximately $1 \times 10^{7}$ infected red cells. ${ }^{17}$ An aliquot of 0.2 $\mathrm{ml}\left(2 \times 10^{7}\right.$ parasitized erythrocytes) of this suspension was injected intraperitoneally into experimental groups. Each animal received inoculums of about 10 million parasites per kilogram body weight, which is expected to produce a steadily rising infection in mice.

\section{Suppressive test}

In vivo anti-malarial activity of Alstonia boonei against Plasmodium berghei: Tests were performed in a 4-day suppressive standard test according. ${ }^{14}$ On day 0 , mice in all groups were inoculated intraperitoneally. ${ }^{14}$ The mice in the test groups received fractions of the extract once daily for 4 days. The control group was administered with distilled water and the standard another group with chloroquine phosphate $(25 \mathrm{mg} / \mathrm{kg}) .{ }^{18}$ For each group of the animals, $0.2 \mathrm{ml}$ of the preparation was administered and gavage was used for oral administration per kg of body weight; the groups are as follow;

\section{Experimental design for in vivo assay}

The animals were divided into 10 groups with which group having 3 mice, doses of $250 \mathrm{mg} / \mathrm{kg}$ and $500 \mathrm{mg} / \mathrm{kg}$ of the extracts of leave and stem bark were administered using two solvent(water and methanol);

Group A; infected group of mice treated with $0.2 \mathrm{ml}$ methanolic extract of leave $(250 \mathrm{mg} / \mathrm{kg})$

Group B; infected group of mice treated with $0.2 \mathrm{ml}$ aqueous extract of leave $(250 \mathrm{mg} / \mathrm{kg})$

Group C; infected group of mice treated with $0.2 \mathrm{ml}$ methanolic extract of leave $(500 \mathrm{mg} / \mathrm{kg})$ 
Group D; infected group of mice treated with $0.2 \mathrm{ml}$ aqueous extract of leave $(500 \mathrm{mg} / \mathrm{kg})$

Group E; infected group of mice treated with $0.2 \mathrm{ml}$ methanolic extract of stem bark $(250 \mathrm{mg} / \mathrm{kg})$

Group F; infected group of mice treated with $0.2 \mathrm{ml}$ aqueous extract of stem bark $(250 \mathrm{mg} / \mathrm{kg})$

Group G; infected group of mice treated with $0.2 \mathrm{ml}$ methanolic extract of stem bark $(500 \mathrm{mg} / \mathrm{kg})$

Group $\mathrm{H}$; infected group of mice treated with $0.2 \mathrm{ml}$ aqueous extract of stem bark $(500 \mathrm{mg} / \mathrm{kg})$

Group I: infected group of mice treated with $0.2 \mathrm{ml}$ of saline water

Group $\mathrm{J}$; infected group of mice treated with $0.2 \mathrm{ml}$ of chloroquine solution $(25 \mathrm{mg} / \mathrm{kg})$.

After infection, parasitemia load was examined daily for four days.

\section{Determination of body weight $(\mathrm{g})$ and temperature $\left({ }^{\circ} \mathrm{C}\right)$ change}

The body weight and temperature of the mice were determined as described by.$^{19}$ Rectal temperatures of mice were obtained using a digital thermometer (BIOSEB-BIO9882). The body weight (BW) of each mouse in all groups was measured every day for 4 days by using a sensitive digital weighing balance and mean BW per group was calculated using the formula:

\section{Mean BW $=\frac{\text { Body weight of mice in a group }}{\text { Total number of mice in that group }}$ \\ Parasitemia count}

On each day of treatment, a drop of blood was collected from each infected mouse for parasitemia screening by tail nip. The blood collected was placed on a slide and smeared to make a thick film, fixed with methanol and stained with Giemsa stain. When dried, the film was microscopically viewed by adding a drop of immersion oil and viewing it under $\mathrm{x} 100$ magnification of the microscope. The parasitemia density was examined by counting the parasitized red blood cell. Percentage parasitaemia suppression was calculated according to the following formula

$$
\begin{aligned}
& \% \text { Parasitaemia }=\frac{\text { Total number of parasitized red blood cells }}{\text { Parasitized red blood cells }} \times 100 \\
& \% \text { Parasitaemia supression }=\frac{(\text { Parasitaemia in control group } \text { Parasitaemia in control group }) \times 100}{\text { Parasitaemia in study group }}
\end{aligned}
$$

\section{Statistical analysis}

Data was statistically analysed using SPSS version 20, the results obtained were statistically analysed using analysis of variance (ANOVA), and tests of significance carried out by New Duncan's multiple range test at $\mathrm{p} \leq 0.05$.

\section{Results}

\section{Qualitative and quantitative phytochemical screening of Alstonia boonei}

Table 1 showed the result of qualitative photochemical analysis of the leaves and stem of Alstonia boonei using water and methanol as solvents. Tannin and phenol were present in the water and methanolic extracts of the stem bark and leaves of the plant, Saponins and anthraquinones were absent in the water and methanolic extracts of the leaves and stem bark. Also, alkaloids were present in the methanolic extract of the leaf and aqueous extract of the stem bark but absent in the methanolic extracts of the stem bark and water extracts of the leaves. Table 2 showed the result of the quantitative phytochemical of the leaves and stem of Alstonia boonei. Tannin was highest $(14.75 \pm 0.09 \%)$ in the methanolic extracts of leaf, equally, alkaloids, terpenoids, oxalates and phenols were highest in the methanolic leaf extracts; $8.780 .01 \%, 7.19 \pm 0.025 \%, 6.12 \pm 0.07 \%$ and $36.88 \pm 0.03 \%$ respectively while steroids were highest in the water extracts of the stem bark $(1.10 \pm 0.01 \%)$.

Table I Qualitative phytochemicals in plant's extracts

\begin{tabular}{lllll} 
Phytochemical & WEL & MEL & WES & MES \\
\hline Tanin & ++ & ++ & + & + \\
Alkaloid & - & + & + & - \\
Terpenoid & - & + & - & + \\
Flavonoids & - & - & + & + \\
Saponin & - & - & - & - \\
Steroids & + & - & + & - \\
Anthraquinone & - & - & - & - \\
Phenols & + & + & + & +
\end{tabular}

Legends: +, slightly present; ++, highly present; - , absent;WEL, water extract of Alstonia boonei leaves; MEL, Methanol extract of Alstonia boonei leaves;WES, water extract of Alstonia boonei stem bark; MES, methanol extract of Alstonia boonei stem bark

Table 2 Qualitative phytochemicals in plant's extracts

\begin{tabular}{lllll}
\hline Phytochemicals & WEL & MEL & WES & MES \\
\hline Tannins (\%) & $14.14 \pm 0.10^{\mathrm{a}}$ & $14.75 \pm 0.09^{\mathrm{a}}$ & $1.59 \pm 0.0 \mathrm{I}^{\mathrm{c}}$ & $1.75 \pm 0.02^{\mathrm{bc}}$ \\
Alkaloids (\%) & $0.00 \pm 0.00^{\mathrm{c}}$ & $8.79 \pm 0.0 \mathrm{I}^{\mathrm{a}}$ & $2.57 \pm 0.03^{\mathrm{b}}$ & $0.00 \pm 0.00^{\mathrm{c}}$ \\
Terpenoids (mg/g) & $0.00 \pm 0.00^{\mathrm{c}}$ & $7.19 \pm 0.02^{\mathrm{a}}$ & $0.00 \pm 0.00^{\mathrm{c}}$ & $4.03 \pm 0.05^{\mathrm{b}}$ \\
Flavonoids (\%) & $0.00 \pm 0.00^{\mathrm{c}}$ & $0.00 \pm 0.00^{\mathrm{c}}$ & $0.69 \pm 0.0 \mathrm{I}^{\mathrm{bc}}$ & $3.95 \pm 0.15^{\mathrm{a}}$ \\
Saponins (\%) & $0.00 \pm 0.00^{\mathrm{a}}$ & $0.00 \pm 0.00^{\mathrm{a}}$ & $0.00 \pm 0.00^{\mathrm{a}}$ & $0.00 \pm 0.00^{\mathrm{a}}$ \\
Steroids (\%) & $0.92 \pm 0.00^{\mathrm{a}}$ & $0.00 \pm 0.00^{\mathrm{b}}$ & $1.10 \pm 0.0 \mathrm{I}^{\mathrm{a}}$ & $0.00 \pm 0.00^{\mathrm{b}}$ \\
Phytates (mg/g) & $5.35 \pm 0.06^{\mathrm{b}}$ & $2.16 \pm 0.03^{\mathrm{c}}$ & $7.00 \pm 0.04^{\mathrm{a}}$ & $7.42 \pm 0.07^{\mathrm{a}}$ \\
Oxalates (mg/g) & $2.34 \pm 0.10^{\mathrm{c}}$ & $6.12 \pm 0.07^{\mathrm{a}}$ & $0.63 \pm 0.02^{\mathrm{d}}$ & $4.05 \pm 0.08^{\mathrm{b}}$ \\
Total phenol (\%) & $35.35 \pm 0.10^{\mathrm{b}}$ & $36.88 \pm 0.03^{\mathrm{a}}$ & $3.98 \pm 0.05^{\mathrm{d}}$ & $4.38 \pm 0.02^{\mathrm{c}}$ \\
\hline
\end{tabular}

Values are presented as Mean $\pm S E M$, values in same row carrying same superscript are not significantly different according to new Duncan's Multiple range test $(p \leq 0.05)$ Legends: $\mathrm{mg} / \mathrm{g}$, milligram per gram; \%, percentage; WEL, water extract of Alstonia boonei leaves; MEL, Methanol extract of Alstonia boonei leaves;WES, water extract of Alstonia boonei stem bark; MES, methanol extract of Alstonia boonei stem bark

\section{Acute toxicity of the extracts of Alstonia boonei}

There was no mortality recorded in the acute toxicity test of the leaf and stem bark of the plant. However, drowsiness was recorded at the concentration above $2000 \mathrm{mg} / \mathrm{kg} /$ body weight in groups fed with stem bark extract and leaf extract.

\section{Weight and temperature of the infected mice at different days of treatment with extracts of $A$. boonei}

The effect of $A$. boonei extracts on body weight of infected mice was shown in Figure 1. During the period of treatment, slight increase in weight was observed in all groups except group $\mathrm{H}$ which was infected with $P$. berghei but treated with normal saline water, weight decreased significantly $(\mathrm{p} \leq 0.05)$ from $20.58 \mathrm{~g}$ to $19.64 \mathrm{~g}$ from day 1 to day 4 of the post-infection period. The effect of $A$. boonei extracts on body temperature of infected mice was shown in Figure 2. In day 1 to 4 of infection, temperature of mice in groups slightly increased except mice in group $\mathrm{H}$. 


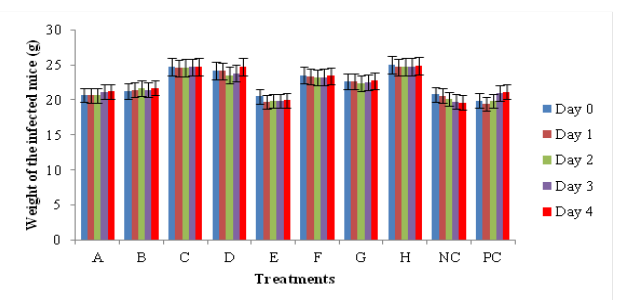

Figure I Weight of the infected mice at different days of treatment.

Legends: Group A; infected group of mice treated with methanolic extract of leaf $(250 \mathrm{mg} / \mathrm{kg})$,

Group B; infected group of mice treated with aqueous extract of leaf $(250 \mathrm{mg} /$ $\mathrm{kg}$ ),

Group C; infected group of mice treated with methanolic extract of leaf $(500 \mathrm{mg} / \mathrm{kg})$,

Group D; infected group of mice treated with aqueous extract of leaf $(500 \mathrm{mg} / \mathrm{kg})$,

Group E; infected group of mice treated with methanolic extract of stem bark $(250 \mathrm{mg} / \mathrm{kg})$,

Group F; infected group of mice treated with aqueous extract of stem bark (250mg/kg),

Group G; infected group of mice treated with methanolic extract of stem bark $(500 \mathrm{mg} / \mathrm{kg})$,

Group $\mathbf{H}$; infected group of mice treated with aqueous extract of stem bark (500mg/kg),

Group I: infected group of mice treated with saline water, (NC)

Group J; infected group of mice treated with chloroquine solution (25mg/ $\mathrm{kg})(\mathrm{PC})$.

$\mathrm{Mg} / \mathrm{kg}$, milligram per kilogram body weight; g, gram

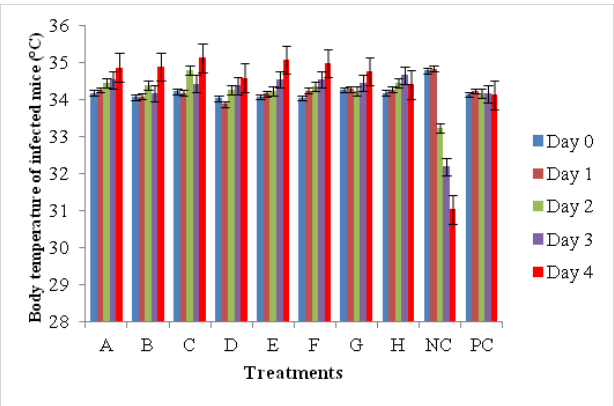

Figure 2 Temperature of the infected mice at different days of treatment. Legends: Group A; infected group of mice treated with methanolic extract of leaf $(250 \mathrm{mg} / \mathrm{kg})$,

Group B; infected group of mice treated with aqueous extract of leaf $(250 \mathrm{mg} /$ $\mathrm{kg}$ ),

Group C; infected group of mice treated with methanolic extract of leaf $(500 \mathrm{mg} / \mathrm{kg})$,

Group D; infected group of mice treated with aqueous extract of leaf $(500 \mathrm{mg} / \mathrm{kg})$,

Group E; infected group of mice treated with methanolic extract of stem bark $(250 \mathrm{mg} / \mathrm{kg})$,

Group F; infected group of mice treated with aqueous extract of stem bark (250mg/kg),

Group G; infected group of mice treated with methanolic extract of stem bark $(500 \mathrm{mg} / \mathrm{kg})$,

Group $\mathbf{H}$; infected group of mice treated with aqueous extract of stem bark (500mg/kg),

Group I: infected group of mice treated with saline water, (NC)

Group J; infected group of mice treated with chloroquine solution $(25 \mathrm{mg} /$ $\mathrm{kg})(\mathrm{PC})$.

$\mathrm{Mg} / \mathrm{kg}$, milligram per kilogram body weight; g, gram

\section{Percentage parasitaemia suppression of Alstonia boonei extracts in the infected mice}

The result shown in Figure 3 and Figure 4 revealed the antiplasmodial activity of methanolic and aqueous extracts of Alstonia boonei stem bark and leaf on infected Swiss albino mice. The result of leaf extracts in Figure 3 revealed that highest parasitaemia suppression $(100 \%)$ was observed in the positive control group followed by the group treated with $500 \mathrm{mg} / \mathrm{kg} /$ body weight of methanol leaf extract $(97.80 \%)$ and group treated with $500 \mathrm{mg} / \mathrm{kg} /$ body weight of aqueous leaf extract however, lowest parasitaemia suppression was observed in group treated with $250 \mathrm{mg} / \mathrm{kg} /$ body weight of aqueous leaf extract. The result of stem bark extracts shown in Figure 4 revealed that there was no significant $(\mathrm{P} \leq 0.05)$ difference in the effect of $250 \mathrm{mg} / \mathrm{kg} /$ body weight of methanol and aqueous extracts while the group treated with $500 \mathrm{mg} / \mathrm{kg} /$ body weight of methanol extract had the highest (89.59) percentage parasitaemia suppression.

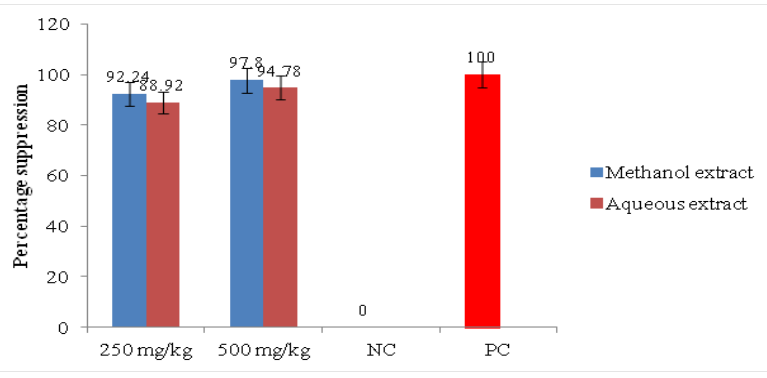

Figure 3 Percentage parasitaemia suppression of Alstonia boonei leaf extracts.

Legend: NC, Negative control group (infected group of mice treated with saline water); PC, Positive control group (infected group of mice treated with chloroquine solution $(25 \mathrm{mg} / \mathrm{kg})$.

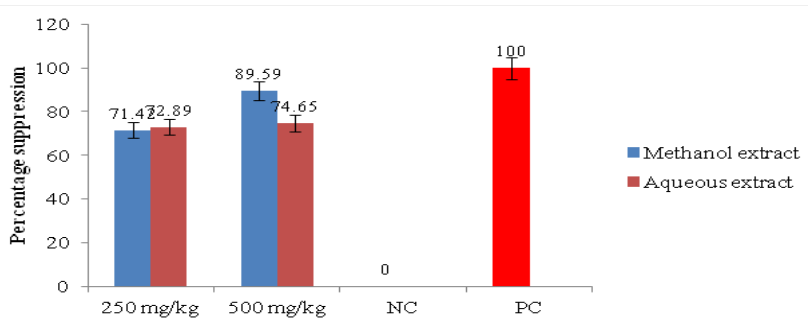

Figure 4 Percentage parasitaemia suppression of Alstonia boonei stem bark extracts.

\section{Discussion}

Plants extracts are considered to be less toxic with fewer adverse effects than synthetic drugs. A growing number of peoples especially in rural communities are therefore turning to alternative therapy, including medicinal plants. The medicinal plants have been used in clinical practice in several countries. The potency of medicinal plants depends solely on their active phytochemical components, which produces a definite physiological action on the human body and is responsible for their numerous bioactivities. The result of the acute toxicity test of administration of $0.2 \mathrm{ml}(2000 \mathrm{mg} / \mathrm{kg}$ per body weight) of stem bark and leaf extracts in this study showed the absence of death although reduction in the activity and drowsiness were observed. The activity observed in mice showed that the extract possess central depressant effect, which coincides with the earlier studies. ${ }^{20}$ 
The decrease in the daily body weight of mice in group I treated with saline water (negative control) was obvious and expected which agrees with Omoya et al. ${ }^{14}$ In addition, the extract (At all doses) treated mice gained weight, compared with the negative control mice that lost weight. Loss of body weight is one of the features of malarial mice and earlier studies demonstrated a decrease in the body weight of malarial mice, compared with healthy mice, ${ }^{21}$ this may be secondary to loss of appetite, reduced food intake and disturbed metabolic functions associated with malaria disease.

Records on body temperature during the study showed that the mice developed hypothermia upon infection with the parasites. Fever is one of the dramatic manifestations of human malaria. In contrast, this model of malaria was associated with hypothermia rather than pyrexia. The infected mice developed profound hypothermia with colonic temperature falling to $31.03^{\circ} \mathrm{C}$. The prolonged development of severe hypothermia in mice can be attributed to the general debilitating effects of malaria on the host, which results in the loss of body heat. The absence of pyrogenic response in this model is due to the fact that small animals like mice have a large surface area-to-body mass ratio, which resulted in a higher degree of heat loss and prevents the development of fever caused by pyrogenic agents. ${ }^{21}$

Comparatively, the methanol leaves extract of Alstonia boonei showed higher parasitaemia suppression than other extracts; this could be due to the presence of phytochemical compounds such as terpenoids, alkaloids, phenols and flavonoids which are thought to be responsible for antiplasmodial activity of most plants. Chloroquine drug used in this study exerted suppression to non detectable level. $A$. boonei methanolic leaf extract caused $88.92 \%$ and $97.86 \%$ at $250 \mathrm{mg}$ / $\mathrm{kg}$ and $500 \mathrm{mg} / \mathrm{kg}$ body weight respectively while the aqueous leave extract caused $84.78 \%$ and $92.24 \%$ suppression in parasitaemia of P. berghei infected mice at $250 \mathrm{mg} / \mathrm{kg}$ and $500 \mathrm{mg} / \mathrm{kg}$ body weight respectively. The significant decrease in parasitemia observed in this study was dose dependent. These effects may be attributed to the presence of alkaloids, terpenes and flavonoids that have been implicated in antiplasmodial activity. ${ }^{14}$ These compounds could be acting singly or in synergy with one another to exert the antiplasmodial activity observed in this study.

\section{Conclusion}

Acute toxicity test result of methanolic and aqueous extracts of the tested leaf and stem bark of Alstonia boonei showed no sign of toxicity in mice treated up to a dose of $2000 \mathrm{mg} / \mathrm{kg}$. Therefore, this supports their traditional use. It was noted in this study that $A$. boonei possessed anti-plasmodium activity justifying its usage in the management of malaria in Nigeria. There may be need to further evaluate, identify and characterize the specific active ingredients responsible for the observed antimalarial activity of the $A$. boonei.

\section{Acknowledgments}

None.

\section{Conflicts of interest}

Authors declare that there is no conflict of interest.

\section{References}

1. World Malaria Report. Geneva: World Health Organization; 2013. 1-46 p.
2. Roll back malaria united nations international children's fund. UNICEF; 2013. 17 p.

3. Abdul-Kareem HA. Malaria, its nature, treatment control and its complications as well as global RBM response. Mia Sc J. 2005;2(2):5.

4. World Malaria Report. Geneva: World Health Organization; 2017. 34 $38 \mathrm{p}$.

5. Idowu OA, Soniran OT, Ajana O, et al. Ethnobotanical survey of antimalarial plants used in Ogun State, Southwest Nigeria. Afr J Pharm Pharmacol. 2010;4(2):55-60.

6. Reddy RC, Vatsala PG. Curcumin for malaria therapy. Biochem Biophys Res Commun. 2005;326(2):472-474.

7. Neto Z, Machado M, Lindeza A, et al. Treatment of Plasmodium chabaudi Parasites with Curcumin in Combination with Antimalarial Drugs: Drug Interactions and Implications on the Ubiquitin/Proteasome System. J Parasitol Res. 2013;2013:429736.

8. Sannella AR, Messori L. Antimalarial properties of green tea. Biochem Biophys Res Commun. 2007;353(1):177-181.

9. Kikueta CM, Kambu OK. In vitro and in vivo antimalarial activity and cytotoxicity of extracts and fractions from the leaves, root-bark and stem-bark of Triclisiagilletii. J Ethnopharmacol. 2013;149(2):438-442.

10. Guidelines for the treatment of malaria. 2nd ed. Geneva: World Health Organization; 2010

11. Jeruto P, Arama PF, Ayango B, et al. In vitro antifungal activity of methanolic extracts of different Senna didymobotryna (FRESEN). Afr J Tradit Complement Altern Med. 2016;13(6):168-174.

12. Emmanuel TI, Muyiwa KO, Haddy N, et al. Microsatellite markers reveal low levels of population sub-structuring of Plasmodium falciparum in southwestern Nigeria. Malaria Journal. 2014;13:493.

13. Odugbemi OO, Akinsulire OR, Aibinu IE, et al. Medicinal plants useful for malarial therapy in Oke-Igbo, Ondo State, Southwest Nigeria. Afr J Tradit Complement Altern Med. 2006;4(2):191-198.

14. Omoya FO, Momoh AO. The Efficacy of Andrographispaniculata and Chromolaenaodorata Plant Extract against Malaria Parasite. International Journal of Biological, Veterinary, Agricultural and Food Engineering. 2014;8(5):1-4.

15. Trease GE, Evans WC. Pharmacognosy.15th Ed. Saunders; 2002. 214 $393 \mathrm{p}$.

16. Lorke D. A new approach to practical acute toxicity testing. Arch Toxicol. 1983;54(4):275-287.

17. David AF, Philip JR, Simon IC, et al. Antimalarial drug discovery: efficacy models for compound screening. Nat Rev. 2004;3(6):509-520.

18. Bantie LM. In vivo antimalarial activity of the crude root and fruit extracts of Croton macrostachyus (Euphorbiaceae) against Plasmodium berghei in mice. J Tradit Complement Med. 2014;5(3):168-173.

19. Dada EO, Oloruntola DA. In vivo Antiplasmodial Activity of Ethanolic Leaf Extract of Tithonia diversifolia (Hemsl.)A. Gray against Plasmodium berghei Nk65 in Infected Swiss Albino Mice. Journal of Applied Life Sciences International. 2016;8(3):1-8.

20. Gbadamosi IT, Moody JO, Lawal AM. Phytochemical screening and proximate analysis of eight ethnobotanicals used as antimalarial remedies in Ibadan. J Appl Biosci. 2011;44:2967-2971.

21. Basir R, Rahiman SF, Hasballah K, et al. Plasmodium bergheiANKA Infection in ICR mice as a model of Cerebral Malaria. Iran J Parasitol. $2012 ; 7(4): 62-74$ 